\title{
COVID-19 and the gastrointestinal tract: more than meets the eye
}

\author{
Siew C Ng $\odot,{ }^{1}$ Herbert Tilg ${ }^{2}$
}

An outbreak of coronavirus disease 2019 (COVID-19), caused by severe acute respiratory syndrome (SARS-CoV-2), has rapidly spread from China to almost all over the world affecting over 800,000 people across 199 countries. Whereas typical presentations of this infection, such as fever, cough, myalgia, fatigue and pneumonia, are well recognised, ${ }^{1-4}$ early studies reported low incidence of typical gastrointestinal (GI) symptoms, such as diarrhoea in the range of $1 \%-3.8 \% .^{1-4}$ Another study suggested a higher rate of GI symptoms with diarrhoea and nausea in $10.1 \%$ and vomiting in $3.6 \% .^{5}$

In GUT several articles report on GI symptoms, detection of the virus in faeces and potential pathophysiological aspects including viral receptor expression in the GI tract. ${ }^{6-12}$ Two large clinical studies from China focused on GI symptoms and detection of the virus in faeces. ${ }^{6}$ Jin et al investigated 74 patients infected with SARS-CoV-2 with GI symptoms such as diarrhoea, nausea and vomiting. Up to $28 \%$ of those with GI symptoms did not have respiratory symptoms. Here, they showed that this patient group compared with patients without GI symptoms $(n=577)$ had overall more severe/critical disease, more patients with fever $>38.5^{\circ} \mathrm{C}$, family clustering and higher rates of liver injury as assessed by elevated aspartate transaminase levels. Among the total studied SARS-CoV-2-infected patients $(n=651)$ $11.4 \%$ experienced GI symptoms, that is, higher rates than reported in previous studies. ${ }^{6}$ In another study, Lin et al investigated 95 SARS-CoV-2-infected patients with special emphasis on GI symptoms. ${ }^{7}$

\footnotetext{
${ }^{1}$ Department of Medicine and Therapeutics, Institute of Digestive Disease, State Key Laboratory of Digestive Disease, Li Ka Shing Institute of Health Sciences, The Chinese University of Hong Kong, Shatin, Hong Kong ${ }^{2}$ Department of Internal Medicine I, Gastroenterology, Hepatology, Endocrinology \& Metabolism, Medical University Innsbruck, Innsbruck, Austria
}

Correspondence to Professor Siew C Ng, Department of Medicine and Therapeutics, Institute of Digestive Disease, State Key Laboratory of Digestive Disease, Li Ka Shing Institute of Health Sciences, The Chinese University of Hong Kong, Shatin, Hong Kong; siewchienng@cuhk.edu.hk and Professor Herbert Tilg, Department of Internal Medicine I, Gastroenterology, Hepatology, Endocrinology \& Metabolism, Medical University Innsbruck, Innsbruck, Austria; herbert.tilg@i-med.ac.at
Overall, 58/95 cases (61.1\%) showed evidence of GI symptoms with diarrhoea (24.2\%), nausea (17.9\%), vomiting (4.2\%) and impaired liver function as assessed by elevated transaminases $(32.6 \%)$ being the most relevant features. Importantly, they performed endoscopy in six subjects demonstrating that SARS-CoV-2 could be detected at various GI locations in three of six subjects in biopsies taken during endoscopy. In two severely diseased patients, the virus could be detected in oesophagus, stomach, duodenum and rectum proving that this virus is present throughout the GI tract. Finally, they were able to detect the virus in $52.4 \%(n=22)$ of assessed faecal samples. Therefore, both studies highlight the prevalence of GI symptoms in COVID-19 disease. In the first case of SARS-CoV-2 infection reported from the USA, the virus was also observed in the stool on day 7 of illness. ${ }^{13}$ Xiao et al investigated 73 SARS-CoV-2infected hospitalised patients in China and $53.4 \%$ patients were tested positive for virus in the stool ranging from day 1 to 12 of infection. ${ }^{14}$ Importantly, in this study, $>20 \%$ of infected patients had positive virus in faeces even after clearance of virus in the respiratory tract. Similar results from Singapore showed that $50 \%$ of their COVID-19 patients had detectable faecal virus but only approximately half of these patients suffered from symptoms such as diarrhoea.' ${ }^{9}$ Therefore, evidence is accumulating that GI symptoms are common and SARS-CoV-2 can be detected in faeces in about $50 \%$ of infected subjects but there appears to be no clear correlation of GI symptoms and detectable virus in the stool.

What remains less clear is why and how SARS-CoV-2 induces GI symptoms and second whether SARS-CoV-2 can be transmitted through the GI tract other than the respiratory tract. A prerequisite of $\mathrm{CoV}$ infection is its entry into the host cells. Akin to its relative SARS-CoV, SARS-CoV-2 uses Angiotensin converting enzyme)-2 (ACE2) as a viral receptor to enter host cells, ${ }^{15-17}$ and ACE2 is an important regulator of intestinal inflammation. ${ }^{18}$ In this issue of GUT, Liang et al examined the expression and distribution of ACE2 in human tissues and different cell populations. By analysing single-cell
RNA sequencing data, they found that ACE2 was highly expressed in the small intestine especially in proximal and distal enterocytes. They also found that two other viral entry receptors for human coronavirus 229E virus and Middle East respiratory syndrome $\mathrm{CoV}$ virus were highly expressed in enterocytes. ${ }^{11}$ To take these findings further, Zhang et al examined ACE2-expressing cell composition and proportion in five public datasets with single-cell transcriptomes of lung, oesophagus, gastric, ileum and colon. ${ }^{8}$ They found that successful virus entry of SARS-CoV-2 depends not only on the presence of cell receptor ACE2 but also the cellular serine protease, transmembrane protease serine 2 (TMPRSS2), which cleaves the $S$ protein of human coronaviruses on the cell membrane, both of which are critical for fusion of viral and the cellular membranes. ${ }^{19}$ ACE2 and TMPRSS2 were not only coexpressed in lung alveolar type 2 cells and oesophageal upper epithelial and gland cells but also highly expressed in the ileum and colon suggesting that the virus can invade enterocytes of the digestive tract. In the oesophagus, ACE2 was highly expressed in the upper and stratified epithelial cells, and this finding may explain SARS-CoV-2 detection in the oesophageal erosion. ${ }^{7}$ An intriguing finding was a higher expression of ACE2 in absorptive enterocytes from the ileum and colon than the lung. ${ }^{8}$ It is unclear whether intestinal inflammation exacerbates ACE2 expression in the gut and exerts an increased risk to patients with inflammatory bowel disease. In this issue of GUT, death was reported in an elderly patient with severe acute ulcerative colitis (on mesalazine) who was treated with high dose intravenous corticosteroids and subsequently developed COVID-19 pneumonia. ${ }^{12}$ Further evidence is required to define the best treatment strategy in patients with IBD especially those with active disease.

In about $50 \%$ of COVID-19 cases, the presence of SARS-CoV-2 in faecal samples and detection of SARS-CoV-2 in intestinal mucosa of infected patients suggest that enteric symptoms could be caused by invasion of ACE2 expressing enterocytes and the GI tract may be an alternative route of infection. In over half of the patients, faecal samples remained positive for SARS-CoV2 RNA for a mean of 11 days after clearance of respiratory tract samples. ${ }^{20}$ A recent study further confirmed that 8 of 10 infected children had persistently positive viral rectal swabs after nasopharyngeal testing was negative. ${ }^{21}$ Importantly, live SARS-CoV-2 was 
detected on electron microscopy in stool samples from two patients who did not have diarrhoea, highlighting the potential of faecal-oral transmission. ${ }^{22}$

In conclusion, these studies provide new insights into our understanding of the prevalence, aetiology and potential mechanisms of COVID-19 in the GI tract crucial for defining prevention measures, clinical care and treatment strategies. Unanswered questions and challenges remain, such as the significance of virus detection in the stool/rectal swabs of asymptomatic subjects, whether ACE2 is a direct mediator for SARS-CoV-2 entry into the GI tract and how the virus could survive passage through extreme $\mathrm{pH}$ environment of the digestive system. Currently, prolonged fecal shedding in infected patients even after viral clearance in respiratory tract suggests that stool testing should be considered in patients with COVID-19 with appropriate transmission precautions for hospitalised patients who remain stool positive. Further research to determine the viability and infectivity of SARS-CoV-2 in faeces is required to control the spread of the virus especially in asymptomatic carriers.

Contributors SCN and HT contibuted equally to the concept and writing of this manuscript.

Funding The authors have not declared a specific grant for this research from any funding agency in the public, commercial or not-for-profit sectors.

Competing interests None declared.

Patient and public involvement Patients and/or the public were not involved in the design, or conduct, or reporting, or dissemination plans of this research.

Patient consent for publication Not required.

Provenance and peer review Commissioned; internally peer reviewed.

\section{(2) OPEN ACCESS}

Open access This is an open access article distributed in accordance with the Creative Commons Attribution
Non Commercial (CC BY-NC 4.0) license, which permits others to distribute, remix, adapt, build upon this work non-commercially, and license their derivative works on different terms, provided the original work is properly cited, appropriate credit is given, any changes made indicated, and the use is non-commercial. See: http:// creativecommons.org/licenses/by-nc/4.0/.

(C) Author(s) (or their employer(s)) 2020. Re-use permitted under CC BY-NC. No commercial re-use. See rights and permissions. Published by BMJ.

\section{Check for updates}

To cite Ng SC, Tilg H. Gut 2020;69:973-974.

Received 26 March 2020

Accepted 27 March 2020

Published Online First 9 April 2020

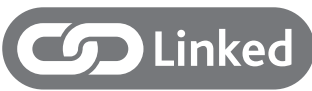

- http://dx.doi.org/10.1136/gutjnl-2020-320926

- http://dx.doi.org/10.1136/gutjnl-2020-321013

- http://dx.doi.org/10.1136/gutjnl-2020-320953

- http://dx.doi.org/10.1136/gutjnl-2020-321051

- http://dx.doi.org/10.1136/gutjnl-2020-320891

- http://dx.doi.org/10.1136/gutjnl-2020-320832

- http://dx.doi.org/10.1136/gutjnl-2020-321183

Gut 2020;69:973-974.

doi:10.1136/gutjnl-2020-321195

\section{ORCID iDs}

Siew C Ng http://orcid.org/0000-0002-6850-4454 Herbert Tilg http://orcid.org/0000-0002-4235-2579

\section{REFERENCES}

1 Zhu N, Zhang D, Wang W, et al. A novel coronavirus from patients with pneumonia in China, 2019. N Engl J Med 2020;382:727-33.

2 Guan W-jie, Ni Z-yi, Hu Y, et al. Clinical characteristics of coronavirus disease 2019 in China. N Engl J Med 2020.

3 Huang C, Wang Y, Li X, et al. Clinical features of patients infected with 2019 novel coronavirus in Wuhan, China. Lancet 2020;395:497-506.

4 Chen N, Zhou M, Dong X, et al. Epidemiological and clinical characteristics of 99 cases of 2019 novel coronavirus pneumonia in Wuhan, China: a descriptive study. Lancet 2020;395:507-13.

5 Wang D, Hu B, Hu C, et al. Clinical characteristics of 138 hospitalized patients with 2019 novel coronavirus-infected pneumonia in Wuhan, China. JAMA 2020;323:1061.

6 Jin X, Lian J-S, Hu J-H, et al. Epidemiological, clinical and virological characteristics of 74 cases of coronavirus-infected disease 2019 (COVID-19) with gastrointestinal symptoms. Gut 2020;69:1002-9.
7 Lin L, Jiang X, Zhang Z, et al. Gastrointestinal symptoms of 95 cases with SARS-CoV-2 infection. Gut 2020:69:997-1001.

8 Zhang $\mathrm{H}$, Kang Z, Gong $\mathrm{H}$, et al. Digestive system is a potential route of COVID-19: an analysis of single-cell coexpression pattern of key proteins in viral entry process. Gut 2020;69:1010-8.

9 Ong J, Young BE, Ong S. COVID-19 in gastroenterology: a clinical perspective. Gut 2020:69:1144-5

10 Song Y, Liu P, Shi XL, et al. SARS-CoV-2 induced diarrhoea as onset symptom in patient with COVID-19. Gut 2020;69:1143-4.

11 Liang W, Feng Z, Rao S, et al. Diarrhoea may be underestimated: a missing link in 2019 novel coronavirus. Gut 2020;69:1141-3.

12 Mazza S, Sorce A, Peyvandi F, et al. A fatal case of COVID-19 pneumonia occurring in a patient with severe acute ulcerative colitis. Gut 2020;69:1148-9.

13 Holshue ML, DeBolt C, Lindquist S, et al. First case of 2019 novel coronavirus in the United States. N Eng/ J Med 2020:382:929-36.

14 Xiao F, Tang M, Zheng $X$, et al. Evidence for gastrointestinal infection of SARS-CoV-2. Gastroenterology 2020. doi:10.1053/j. gastro.2020.02.055. [Epub ahead of print: 03 Mar 2020].

15 Zhou P, Yang X-L, Wang X-G, et al. A pneumonia outbreak associated with a new coronavirus of probable bat origin. Nature 2020;579:270-3.

16 Wan Y, Shang J, Graham R, et al. Receptor recognition by the novel coronavirus from Wuhan: an analysis based on decade-long structural studies of SARS coronavirus. J Virol 2020;94. doi:10.1128/JVI.0012720. [Epub ahead of print: 17 Mar 2020].

17 Wan Y, Shang J, Sun S, et al. Molecular mechanism for antibody-dependent enhancement of coronavirus entry. J Virol 2020;94.

18 Hashimoto T, Perlot T, Rehman A, et al. ACE2 links amino acid malnutrition to microbial ecology and intestinal inflammation. Nature 2012;487:477-81.

19 Hoffmann M, Kleine-Weber H, Schroeder S, et al. SARS-COV-2 cell entry depends on ACE2 and TMPRSS2 and is blocked by a clinically proven protease inhibitor. Cell 2020. doi:10.1016/j.cell.2020.02.052. [Epub ahead of print: 04 Mar 2020]

20 Wu Y, Guo C, Tang L, et al. Prolonged presence of SARS-CoV-2 viral RNA in faecal samples. Lancet Gastroenterol Hepatol 2020. doi:10.1016/S2468 1253(20)30083-2. [Epub ahead of print: 19 Mar 2020].

21 Xu Y, Li X, Zhu B, et al. Characteristics of pediatric SARS-CoV-2 infection and potential evidence for persistent fecal viral shedding. Nat Med 2020;395.

22 Wang W, Xu Y, Gao R, et al. Detection of SARS-CoV-2 in different types of clinical specimens. JAMA 2020. doi:10.1001/jama.2020.3786. [Epub ahead of print: 11 Mar 2020]. 